\title{
Vermikompos Sampah Kebun dengan Menggunakan Cacing Tanah Eudrilus eugeneae dan Eisenia fetida
}

\author{
Etik Rahmawati dan Welly Herumurti \\ Jurusan Teknik Lingkungan, Fakultas Teknik Sipil dan Perencanaan, \\ Institut Teknologi Sepuluh Nopember (ITS) \\ Jl. Arief Rahman Hakim, Surabaya 60111 Indonesia \\ e-mail: herumurti@enviro.its.ac.id
}

\begin{abstract}
Abstrak-Durasi yang panjang diperlukan dalam pengomposan konvensional sampah organik yang memerlukan waktu selama 2-3 bulan. Pengurangan waktu pengomposan dapat dilakukan dengan digunakannya cacing sebagai dekomposer. Penelitian ini bertujuan untuk menentukan tingkat degradasi sampah kebun menggunakan proses vermikomposting dan menentukan pengaruh jenis cacing Eudrilus eugeneae dan Eisenia fetida. Empat reaktor berukuran $8 \mathrm{~L}$ digunakan dalam penelitian ini. Percobaan dilakukan secara duplo selama 60 hari. Parameter yang dianalisis pada penelitian ini adalah ammonia nitrogen $\left(\mathrm{NH}_{3}-\mathrm{N}\right)$, nitrat nitrogen $\left(\mathrm{NO}_{3}-\right.$ N), Total Kjeldahl Nitrogen (TKN), dan C/N. Hasil penelitian menunjukkan bahwa tingkat degradasi sampah kebun dengan pengolahan vermikomposting yang dapat dicapai adalah 64,94-72,52\%. Produksi kompos yang lebih tinggi dengan penggunaan Eisenia fetida.
\end{abstract}

Kata kunci: Eisenia sp., Eudrilus sp., kotoran sapi, sampah kebun, vermikompos

\section{PENDAHULUAN}

$\mathrm{K}^{\mathrm{o}}$ OMPOSISI sampah di Indonesia didominasi oleh sampah organik yang merupakan sampah biodegradable. Sebagai contoh komposisi sampah organik di Surabaya yang mencapai $71,96 \%$ pada tahun 2012 [1]. Pengolahan sampah yang dilakukan di Surabaya menggunakan sistem landfilling yang membutuhkan biaya yang tinggi [2]. Reduksi sampah biodegradable ini perlu dilakukan untuk mengurangi biaya landfilling yang dikeluarkan oleh pemerintah.

Reduksi sampah biodegradable yang banyak dilakukan di Indonesia adalah dengan menggunakan sistem komposting. Komposting merupakan salah satu metode pengolahan sampah organik dengan cara dekomposisi material organik secara aerobik. Kompos yang dihasilkan dapat digunakan pada kegiatan pertanian [3]. Jenis sampah biodegradable yang sering diolah dengan menggunakan metode pengomposan adalah sampah kebun. Namun, komposting memiliki kelemahan diantaranya kompos yang dihasilkan memiliki kandungan nutrisi yang rendah dan membutuhkan waktu yang lama dalam proses pematangannya. Hal ini lah yang menyebabkan pemanfaatan kompos jarang dilakukan [3].

Vermikomposting merupakan salah satu alternatif pengolahan sampah kebun yang sesuai dengan kondisi iklim di
Indonesia. Kompos yang dihasilkan, atau yang biasa disebut dengan cascing memiliki kandungan nutrisi yang lebih baik jika dibandingkan dengan kompos konvensional. Kelebihan lain vermikomposting adalah tidak menimbulkan bau, biaya pengolahan yang rendah, dan tidak menimbulkan polusi dan pathogen [3]. Optimalisasi penurunan volume sampah dengan menggunakan metode ini belum dapat diketahui secara pasti. Fokusan penelitian yang ada hanya mempelajari produksi cascing. Oleh karena itu, penelitian ini bertujuan untuk menentukan tingkat degradasi sampah kebun dengan menggunakan metode vermikomposting.

Setiap jenis cacing memiliki kemampuan mendegradasi material organik yang berbeda-beda. Hal ini dikarenakan adanya perbedaan karakteristik makanan yang dapat dikonsumsi oleh cacing. Eisenia fetida dan Eudrellus eugineae merupakan pemakan berbagai variasi material degradable yang baik digunakan untuk vermikomposting [2]-[4].

\section{URAIAN PENELITIAN}

\section{A. Bahan Baku vermikompos dan Reaktor}

Sampah yang digunakan adalah sampah kebun yang diambil dari Rumah Kompos ITS. Sampah dicacah menggunakan alat pencacah yang digunakan di lokasi tersebut sehingga ukurannya dapat seragam. Karakteristik awal sampah kebun ditunjukkan pada tabel 1. Dilakukan pemilahan antara ranting dan daun, sehingga sampah yang digunakan mudah untuk terdegradasi. Cacing yang digunakan adalah cacing Eudrilus eugeniae dan Eisenia fetida yang berasal dari tempat budidaya cacing di Cimahi, Bandung, Jawa Barat. Umur cacing yang digunakan seragam, yaitu 4 bulan. Reaktor berbentuk kotak volume $8 \mathrm{~L}$ dengan bahan plastik. Reaktor ini dipilih berdasarkan pertimbangan volume dan konvigurasi reaktor yang memiliki perbandingan panjang dan kedalaman reaktor yang proporsional [5]. Substrat pada bagian bawah dijaga agar tidak sampai menyentuh bagian bawah reaktor untuk menjaga agar lindi yang terbentuk tidak bercampur dengan sebstrat dengan menggunakan kassa sebagai penyangga.

600 gram (berat kering) sampah kebun yang telah dilakukan pre komposting selama 7 hari dimasukkan kedalam reaktor, 9 gram (berat kering) cacing Eudrilus sp. dan Eisenia sp. dimasukkan ke dalam reaktor setelah dilakukan aklimatisasi. Aklimatisasi dilakukan pada cacing dan substrat. 
Aklimatisasi ini bertujuan untuk mempersiapkan cacing yang digunakan pada percobaan dan substrat sebagai media tumbuh cacing agar mikroorganisme dalam keadaan stabil. Aklimatisasi cacing dilakukan pada media kompos sampah daun, sedangkan pada aklimatisasi sampah daun dilakukan dengan membiarkan sampah daun yang sudah tercampur pada reaktor selama 3 hari.

Tabel 1. Karakteristik Awal Sampah Kebun

\begin{tabular}{|c|c|}
\hline Densitas (g/L) & 396,5 \\
\hline Kadar air (\%) & 59,02 \\
\hline pH & 7,64 \\
\hline Suhu $\left({ }^{\circ} \mathbf{C}\right)$ & 35 \\
\hline TOC (\%) & 27,53 \\
\hline TKN (\%) & 1,47 \\
\hline $\mathbf{N H}_{3}-\mathbf{N}(\%)$ & 0,02 \\
\hline $\mathbf{N O}_{3}-\mathbf{N}(\%)$ & 0,41 \\
\hline $\mathbf{V s}(\%)$ & 47,47 \\
\hline
\end{tabular}

\section{B. Metode Analisis}

Analisis TOC menggunakan metode gravimetri. TKN dianalisis dengan menggunakan metode Kjeldahl menggunakan Kjeldahl Aparatus dengan analisis akhirnya menggunakan metode nesler. Ammonia nitrogen $\left(\mathrm{NH}_{3}-\mathrm{N}\right)$ merupakan pengukuran konsentrasi nitrogen dalam senyawa ammonia dianalisis menggunakan metode nesler. Nitrat nitrogen $\left(\mathrm{NO}_{3}-\mathrm{N}\right)$ dianalisis dengan menggunakan brucin acetat. Tingkat degradasi diketahui dengan dilkukan pengayakan menggunakan ayakan berukuran 4 mesh.

\section{HASIL DAN PEMBAHASAN}

\section{A. Total Organic Carbon}

Konsentrasi TOC mengalami penurunan. Penurunan kosentrasi TOC dapat dilihat pada Gambar 1. Penurunan konsentrasi TOC ini dapat disebabkan karena adanya aktivitas respirasi dan asimilasi mikroorganisme dan cacing. Aktivitas ini mengubah $\mathrm{C}$ organik yang tersedia menjadi $\mathrm{CO}_{2}$ gas [6]. Degradasi TOC pada reaktor dengan penambahan Eisenia sp. lebih tinggi jika dibandingkan dengan reaktor yang ditambahkan dengan Eudrilus sp. Hal ini menunjukkan bahwa cacing Eisenia $s p$. memiliki kemampuan yang lebih baik dalam penurunan konsentrasi TOC jika dibandingkan dengan Eudrilus sp. Hal ini dibenarkan oleh Singh et al [7] yang menyebutkan bahwa diantara lima jenis cacing (Eisenia fetida, Dendrobaena veneta, Eudrilus eugeneae, Perionyx excavates dan Pheretima hawayana), Eisenia sp. merupakan spesies yang terbaik untuk digunakan dalam vermistabilisasi. Cacing akan memakan material organik, temasuk karbon, dengan menggunakan organ tubuhnya kemudian melewati permukaan substrat yang menyebabkan meningkatnya aktivitas mikroorganisme yang berperan dalam mendegradasi substrat karena adanya kondisi yang aerobik [7]. Kondisi yang aerobik ini akan mempercepat trasformasi material organik dan mengubah mineral yang tidak tersedia menjadi mineral yang tersedia yang dapat diserap dengan mudah oleh tanaman [7]. Hal inilah yang menyebabkan reaktor kontrol $(\mathrm{K})$ mengalami penurunan konsentrasi TOC lebih rendah jika dibandingkan dengan reaktor dengan penambahan Eisenia sp. (E) dan Eudrilus sp. (A).

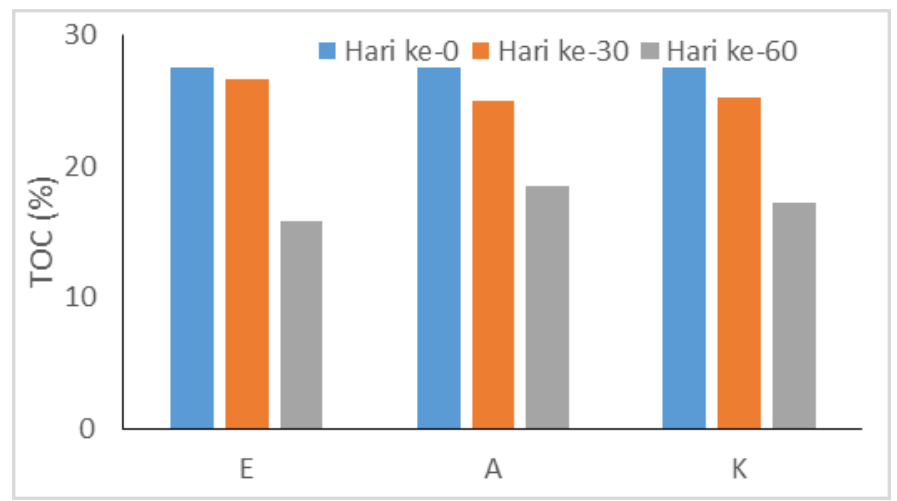

Gambar 1. Penurunan Konsentrasi TOC

\section{B. Total Kjeldahl Nitrogen}

Hasil analisis konsentrasi TKN menunjukkan bahwa pada hari ke-30 reaktor A dan $\mathrm{K}$ mengalami kenaikan konsentrasi TKN, namun pada reaktor E mengalami penurunan. Pada hari ke-60 semua reaktor mengalami penurunan TKN. Penurunan TKN dimungkinkan karena adanya konsumsi nitrogen oleh cacing yang diubah menjadi bentuk protein [8]. Nitrogen organik dibutuhkan cacing dan mikroorganisme dalam proses metabolisme. Penurunan TKN juga terjadi pada penelitian vermikompos sampah sayur yang dilakukan oleh Huang et al [10] dan Lalander et al [12], penurunan yang terjadi lebih kecil jika dibandingkan dengan pengomposan tanpa penambahan cacing. Sedangkan peningkatan TKN yang terjadi dikarenakan penambahan nitrogen yang dilakukan oleh mikroorganisme dan cacing lebih besar jika dibandingkan dengan konsumsi nitrogen oleh mikroorganisme dan cacing. Penambahan nitrogen oleh cacing dapat berbentuk lendir, enzim, atau ekskresi material yang mengandung nitrogen [13]. Selain itu kematian cacing juga dapat menyebabkan peningkatan konsentrasi TKN, hal ini dikarenakan tubuh cacing terdiri dari $65 \%$ protein yang merupakan sumber $\mathrm{N}$ organik [7].

\section{Ammonia Nitrogen}

Konsentrasi ammonia nitrogen mengalami penurunan pada hari ke-30 dan mengalami kenaikan pada hari ke-60. Ammonia meningkat karena adanya penambahan ammonia oleh cacing dan mikroorganisme dari proses ekskresi. Huang et al [10] mencatat kenaikan ammonia pada vermikomposting sampah sayur dengan menggunakan Eisenia sp. Ammonia merupakan senyawa yang akan diubah oleh nitrobakter menjadi nitrat. Nitrobakter akan meningkat dikarenakan adanya lendir pada cacing yang memperkaya jumlah nitrobakter. Semakin banyak lendir yang dihasilakan maka jumlah bakteri yang terkandung di dalam substrat akan semakin banyak. Pada reaktor yang mengalami penurunan konsentrasi ammonia dimungkinkan karena laju ekskresi cacing dalam bentuk ammonia lebih sedikit jika dibandingkan dengan laju ammonia yang diubah menjadi nitrat. Peningkatan konsentrasi ammonia tertinggi pada reaktor E. sedangkan penurunan konsentrasi ammonia tertinggi pada reaktor $\mathrm{K}$. 


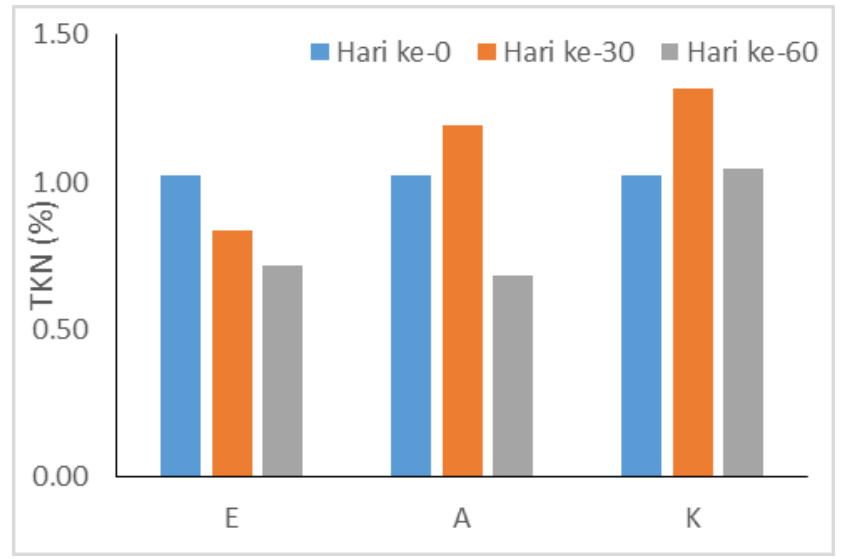

Gambar 2. Perubahan Konsentrasi TKN

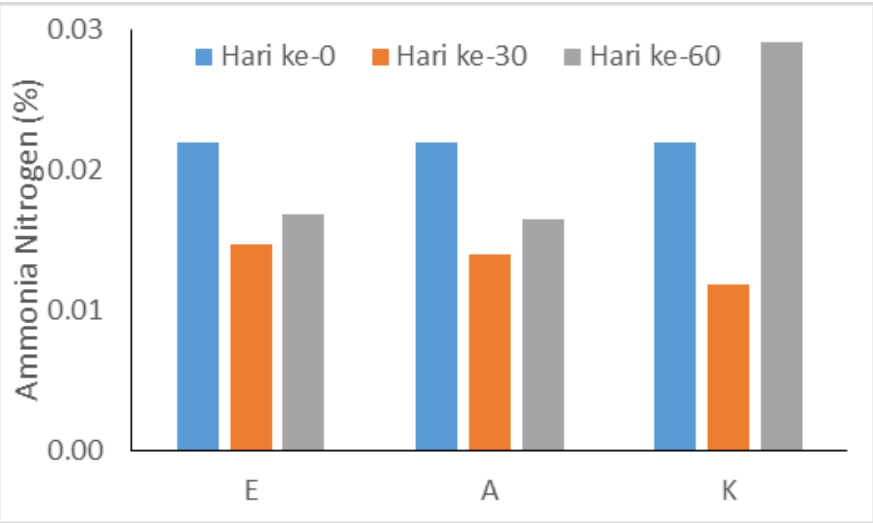

Gambar 3. Perubahan Konsentrasi Ammonia

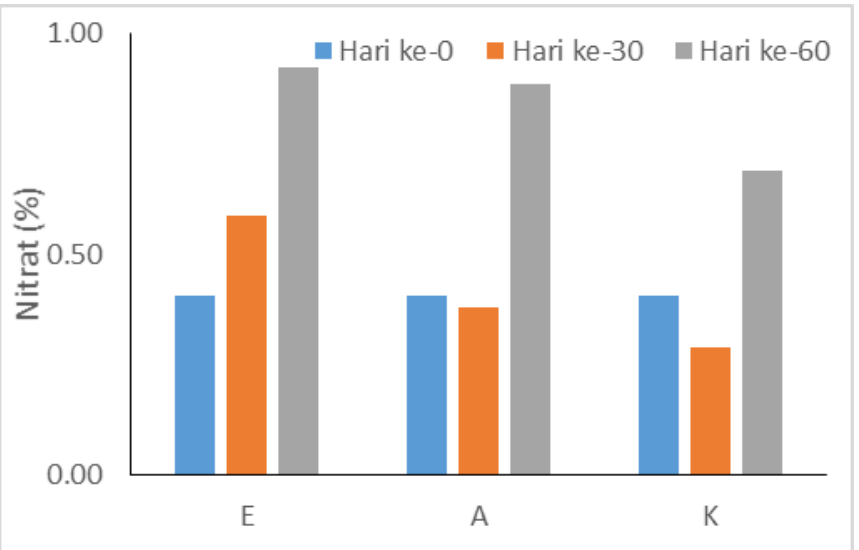

Gambar 4. Perubahan Konsentrasi Nitrat

\section{Nitrat Nitrogen}

Nitrat nitrogen merupakan senyawa anorganik yang dihasilkan dari degradasi nitrogen organik melalui proses nitrifikasi. Pada penelitian konsentrasi nitrat mengalami penurunan pada hari ke-30 kemudian mengalami kenaikan pada hari ke-60. Penurunan konsentrasi nitrat dimungkinkan adanya nitrifikasi yang menyebabkan nitrat diubah menjadi $\mathrm{N}_{2}$ gas. Sedangkan peningkatan nitrat disebabkan adanya aktivitas mikroorganisme yang mengubah $\mathrm{N}$ organik menjadi ammonia kemudian menjadi nitrat. Peningkatan nitrat juga terjadi pada penelitian Suthar and Sharma [14] dengan peningkatan nitrat hingga mencapai 5 kali lipat. Huang et al [10] mencatat peningkatan konsentrasi nitrat tertinggi pada vermikomposting sampah sayur mencapai 7 kali lipat dengan menggunakan
Eisenia sp. Peningkatan konsentrasi nitrat merupakan indikasi bahwa cacing dan mikroorganisme berperan dalam mineralisasi nitrogen [14].

Peranan cacing dalam meningkatkan konsentrasi nitrat di dalam substrat dibuktikan dengan peningkatan konsentrasi nitrat pada reaktor $\mathrm{E}$ dan $\mathrm{A}$ yang lebih tinggi jika dibandingkan dengan peningkatan konsentrasi nitrat pada reaktor $\mathrm{K}$. Hal ini dikarenakan adanya penggabungan dari lendir, material ekskresi, hormon pertumbuhan, dan enzim yang mengandung nitrogen yang berasal dari cacing [14]. Material tersebut mudah didegradasi oleh bakteri nitrifikasi menjadi nitrat, sehingga peningkatan konsentrasi nitrat pada reaktor yang ditambahkan cacing lebih besar. Singh et al [7] juga mencatat peningkatan nitrat dengan metode vermikomposting lebih tinggi jika dibandingkan dengan komposting konvensional. Reaktor E dapat meningkatkan konsentrasi nitrat $34 \%$ lebih tinggi jika dibandingkan dengan reaktor K, sedangkan reaktor A $28 \%$ lebih tinggi dari reaktor $\mathrm{K}$. Hal ini menunjukkan Eisenia sp. dapat menghasilkan kompos dengan konsentrasi nitrat yang lebih tinggi jika dibandingkan dengan Eudrilus sp.

\section{E. C/N Kompos}

$\mathrm{C} / \mathrm{N}$ merupakan salah satu indikator kematangan dan kualitas agronomik kompos [15]. Nilai C/N dibawah 20 menunjukkan bahwa kompos telah matang, sedangkan jika nilai $\mathrm{C} / \mathrm{N}$ sama dengan atau lebih kecil dari 15 , menunjukkan bahwa kompos memiliki nilai agronomik yang tinggi [15]. C/N total pada semua reaktor menunjukkan penurunan. Penurunan ini dikarenakan adanya penurunan konsentrasi TOC dan peningkatan konsentrasi $\mathrm{N}$ total. $\mathrm{N}$ total merupakan penjumlahan dari TKN, ammonia nitrogen, dan nitrat nitrogen.

Pada penelitian ini semua reaktor mengalami penurunan $\mathrm{C} / \mathrm{N}$ total. Penurunan tertinggi terjadi pada reaktor $\mathrm{E}$ dan yang terendah adalah pada reaktor A. Reaktor A mengalami penurunan yang paling kecil disebabkan adanya cacing yang mati yang kemudian terbaca sebagai $\mathrm{C}$ organik, sehingga konsentrasi TOC mengalami penurunan yang kecil. Tubuh cacing mengandung $14 \%$ karbohidrat yang merupakan sumber C organik [3], sehingga kematian cacing akan menambah nilai $\mathrm{C}$ organik pada substrat. Selain itu adanya peningkatan jumlah biomassa mikroorganisme dan jamur dalam substrat juga akan menyebabkan kenaikan konsentrasi TOC [6]. Hasil penelitian yang dilakukan oleh Suthar dan Gairola [6] yang meneliti vermikompos dengan sampah daun dan penambahan kotoran sapi juga mengalami peningkatan TOC pada hari ke-30. Namun pada semua reaktor telah memenuhi kriteria $\mathrm{C} / \mathrm{N}$ kompos menurut SNI 19-7030-2004 yaitu 10-20. Reaktor E memiliki nilai $\mathrm{C} / \mathrm{N}$ akhir dibawah SNI, yaiti 9,5. Hal ini dikarenakan kandungan nitrat yang tinggi pada kompos, sehingga kualitas kompos reaktor $\mathrm{E}$ lebih baik jika dibandingkan dengan reaktor yang lain.

\section{F. Produksi Kompos}

Produksi kompos tertinggi terjadi pada reaktor E, yaitu dengan penambahan cacing Eisenia sp. dengan \% produksi kompos sebesar $72,52 \%$, sedangkan reaktor A mengalami degradasi menjadi kompos sebesar 64,94\%. Degradasi 
terendah terjadi pada reaktor $\mathrm{K}$ dengan tingkat degradasi $58,17 \%$. Hal ini menunjukkan bahwa penambahan cacing pada proses pengomposan dapat meningkatkan produksi kompos. Peningkatan produksi kompos terbesar dapat dilakukan dengan penambahan cacing Eisenia sp. sebagai dekomposer. Sehingga Eisenia sp. merupakan spesies yang terbaik untuk digunakan dalam pengomposan sampah kebun.

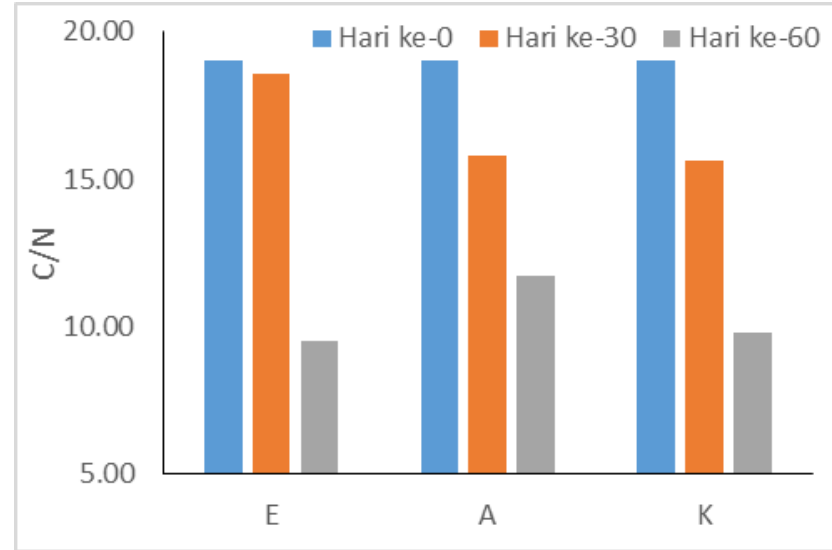

Gambar 5. Nilai C/N total Kompos

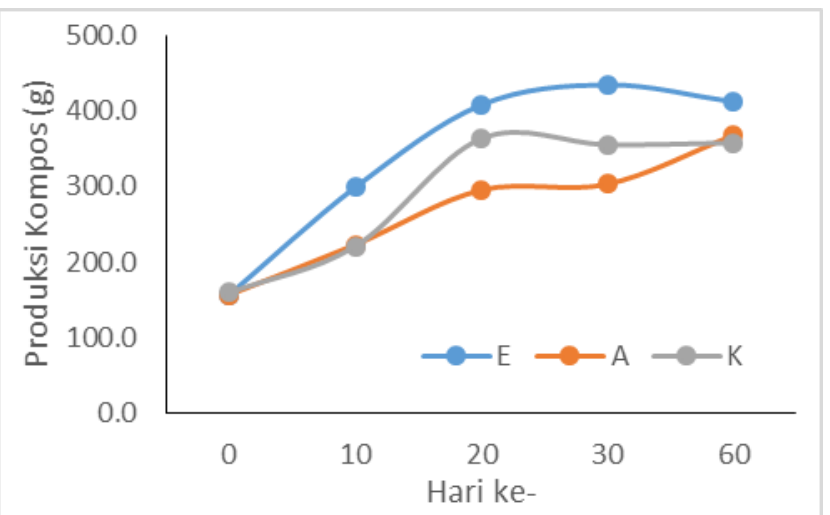

Gambar 6. Produksi Kompos

\section{KESIMPULAN}

Degradasi sampah kebun pada proses pengomposan dapat ditingkatkan dengan menambahkan cacing tanah sebagai dekomposer. Eisenia sp. dapat meningkatkan degradasi sampah kebun pada proses pengomposan sebesar 14,35\%, sedangkan Eudrilus sp. dapat meningkatkan degradasi sampah kebun sebesar 6,77\%. Penambahan cacing juga dapat meningkatkan konsentrasi nitrat sebesar $34 \%$ pada penambahan cacing Eisenia sp. dan $28 \%$ pada penambahan cacing Eudrilus sp.

\section{UCAPAN TERIMA KASIH}

Ucapan terima kasih disampaikan kepada Direktorat Pendidikan Tinggi, Departemen Pendidikan dan Kebudayaan Republik Indonesia yang telah memberikan dukungan finansial melalui Beasiswa Bidik Misi tahun 2011-2015. Ucapan terima kasih disampaikan pula kepada Kementerian Riset, Teknologi, dan Pendidikan Tinggi Republik Indonesia atas pendanaan hibah Penelitian Unggulan Perguruan Tinggi.

\section{DAFTAR PUSTAKA}

[1] L. Nikmah and I. D. A. . Warmadewanti, "Prediksi Potensi Pencemaran Pengolahan Sampah dengan Metode Gasifikasi Fluidized Bed," POMITS, vol. 2, no. 0, p. D14, 2013.

[2] E. K. Anwar, "Efektivitas Cacing Tanah Pheretima hupiensis, Edrellus sp. dan Lumbricus sp. dalam Proses Dekomposisi Bahan Organik," J Tanah Trop, vol. 14, pp. 149-158, Mar. 2009.

[3] R. P. Singh, P. Singh, A. S. F. Araujo, M. Hakimi Ibrahim, and O. Sulaiman, "Management of urban solid waste: Vermicomposting a sustainable option," Resour. Conserv. Recycl., vol. 55, no. 7, pp. 719-729, May 2011.

[4] S. Gajalakshmi and S. A. Abbasi, "Earthworms and vermicomposting," Indian J. Biotecnol., vol. 3, pp. 486494, Oktober 2004.

[5] P. S. Ganesh, S. Gajalakshmi, and S. A. Abbasi, "Vermicomposting of the leaf litter of acacia (Acacia auriculiformis): Possible roles of reactor geometry, polyphenols, and lignin," Bioresour. Technol., vol. 100, no. 5, pp. 1819-1827, Mar. 2009.

[6] S. Suthar and S. Gairola, "Nutrient recovery from urban forest leaf litter waste solids using Eisenia fetida," Ecol. Eng., vol. 71, no. 0, pp. 660-666, Oct. 2014.

[7] R. P. Singh, A. Embrandiri, M. H. Ibrahim, and N. Esa, "Management of biomass residues generated from palm oil mill: Vermicomposting a sustainable option," Resour. Conserv. Recycl., vol. 55, no. 4, pp. 423-434, Feb. 2011.

[8] M. J. Fernández-Gómez, R. Nogales, H. Insam, E. Romero, and M. Goberna, "Continuous-feeding vermicomposting as a recycling management method to revalue tomato-fruit wastes from greenhouse crops," Waste Manag., vol. 30, no. 12, pp. 2461-2468, Dec. 2010.

[9] K. Huang, F. Li, Y. Wei, X. Chen, and X. Fu, "Changes of bacterial and fungal community compositions during vermicomposting of vegetable wastes by Eisenia foetida," Bioresour. Technol., vol. 150, no. 0, pp. 235-241, Dec. 2013.

[10] K. Huang, F. Li, Y. Wei, X. Fu, and X. Chen, "Effects of earthworms on physicochemical properties and microbial profiles during vermicomposting of fresh fruit and vegetable wastes," Bioresour. Technol., vol. 170, no. 0, pp. 45-52, Oct. 2014.

[11] C. H. Lalander, A. J. Komakech, and B. Vinnerås, "Vermicomposting as manure management strategy for urban small-holder animal farms - Kampala case study," Waste Manag., no. 0, 2015.

[12] C. H. Lalander, A. J. Komakech, and B. Vinnerås, "Vermicomposting as manure management strategy for urban small-holder animal farms - Kampala case study," Waste Manag., no. 0, 2015.

[13] S. L. Lim, T. Y. Wu, E. Y. S. Sim, P. N. Lim, and C. Clarke, "Biotransformation of rice husk into organic 
fertilizer through vermicomposting," Ecol. Eng., vol. 41, no. 0, pp. 60-64, Apr. 2012.

[14] S. Suthar and P. Sharma, "Vermicomposting of toxic weed - Lantana camara biomass: Chemical and microbial properties changes and assessment of toxicity of end product using seed bioassay," Ecotoxicol. Environ. Saf., vol. 95, no. 0, pp. 179-187, Sep. 2013.

[15] S. Suthar, "Vermicomposting of vegetable-market solid waste using Eisenia fetida: Impact of bulking material on earthworm growth and decomposition rate," Ecol. Eng., vol. 35, no. 5, pp. 914-920, May 2009. 